\title{
OPTIMIZATION TO MINIMIZING DISTANCE CARS OF FIRE EXPORTER IN INDUSTRIAL REGION SIER SURABAYA
}

\author{
Muhamad Abdul Jumali *) \\ ${ }^{*}$ Industrial Engineering Department, Faculty of Industrial Technology \\ University of PGRI Adi Buana Surabaya \\ email :abduljumali@unipasby.ac.id
}

\begin{abstract}
Various fire infrastructure in Surabaya has been built, but the number of fire incident is less suitable with the standard of disaster response time. This study was conducted to determine the distribution of minimization of fire engine mileage in SIER Industrial Area of Surabaya. The analytical method used is qualitative descriptive by comparing existing condition, criteria, and policy review that exist in SIER Industrial Area of Surabaya with data of fire service post service in Surabaya City to know unreached area of fire post service and have high risk potential Will be a fire disaster in the SIER Industrial Area of Surabaya. Next determine the factors and criteria for determining the location of firefighting post based on existing policy studies and conditions. Factors determining the location of firefighting in Surabaya City is a function of the building based on the type of land use, the density of the net population, the density of the building, the range of fire service, the radius of the water supply range, the incidence of fire, the time of fire disaster response, the availability of land, and the class of road. The result of this research is the implementation of building protection management on building function in industrial area, procurement of socialization and education of fire prevention for the community, coordinating with traffic police to facilitate path of location achievement.
\end{abstract}

Keywords: distribution, firefighting post, location, potential risk.

\section{Introduction}

Several incidents of urban fires such as Jakarta, Surabaya, Semarang, Medan and many others have claimed casualties because the victims were unable to get out of the building where the fires were due to physical limitations, especially in industrial areas that employ many workers. The incident caused the death toll could not be recognized because there are burns all over the body.

Setting the location of the fire station as an emergency service facilityrequiresspecialconsiderations. So far almost in all industrial areas in Indonesia therehas been noappropriate emergency service conditions, both in the number of facilities and equitable distribution. Research on the location of firefighting posts is important in the consideration of reducing the impact or risk of loss (casualties, property, buildings, and public facilities). One way of setting fire location is to use the model as a simplification of the existing reality. The use of the model as an approximation is expected to be applicable forother regions in Indonesia. Modeling to be used by compiling information system applications spatial reference, Geographic Information System (GIS). (Effendi: 2003, Ardian: 2008, Febby: 2009). Research by Mohammad Bagir with the title of final task of Models of Post-Location Fire Extinguishers(Semarang city) in 2009 which examines the development that does not refer to the aspects of planning resulted in unexpected results. For example, in an industrial area built capable of absorbing new employment and improving the economy of any region if it ignores the good drainage arrangements, planned waste development system, appropriate site selection, fire resistant building structures, and provision of evacuation routes in case of fire can lead to environmental problems and the risk of disasters such as floods, landslides, droughts, and fires. The high intensity of fires in urban areas has so far caused widespread 
implications concerning social, economic, psychological, mass, political and environmental aspects. In the condition of the economy that has not fully recovered, it is necessary effective fire management efforts regarding the prevention and control. This research aims to be able to know the closest distance for the distribution of fire trucks in the industrial area of SIER Surabaya.

\section{Methods}

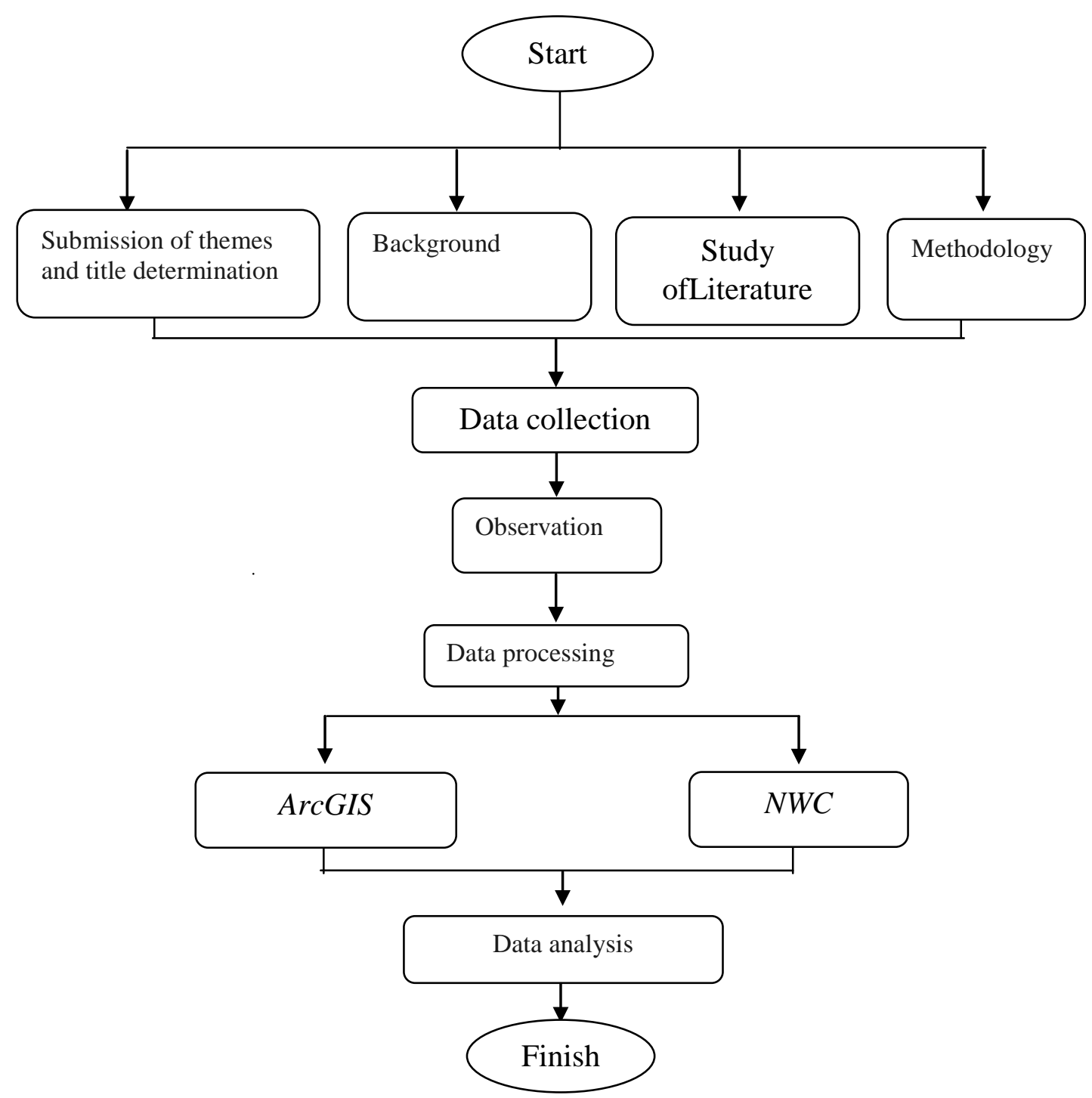

Figure 1.Research Flow

The types and methods used to analyze the data obtained in the study to prove or test the truth of existing hypotheses. In analyzing the data, the author uses North West Corner (NWC). (Sunyoto, 2009) The subject of research is the distance of the nearest firefighting post with the industrial area of SIER Surabaya. Here are the calculation steps with NWC:

A. Compare between demand $\left(\mathrm{a}_{1}\right)$ withsupply $\left(\mathrm{b}_{1}\right)$ andif :

1) $\left(a_{1}\right) \geq\left(b_{1}\right) \Rightarrow X_{11}=b_{1}$, and the next step moves vertically down $(2,1)$.
2) $\left(a_{1}\right) \leq\left(b_{1}\right) \Rightarrow X_{11}=a_{1}$, and the next move On horizontal $(1,2)$.

3) $\left(a_{1}\right) \leq\left(b_{1}\right) \Rightarrow X_{11}=a_{1}=b_{1}$, and the next step moves diagonally down $(2,2)$.

4) Calculate $X_{\mathrm{ij}}$ according to the result in step 1 , the process is continued and ended in the cell $(n, m)$.

5) Determining the value of purpose function (total transportation cost). Based on transportation troubleshooting steps by method North West Corner (NWC) . 


\section{TiBuana}

Journal of applied Industrial Engineering-University of PGRI Adi Buana

p-ISSN 2622-2027

$e$-ISSN 2622-2035

\section{Result and discussion}

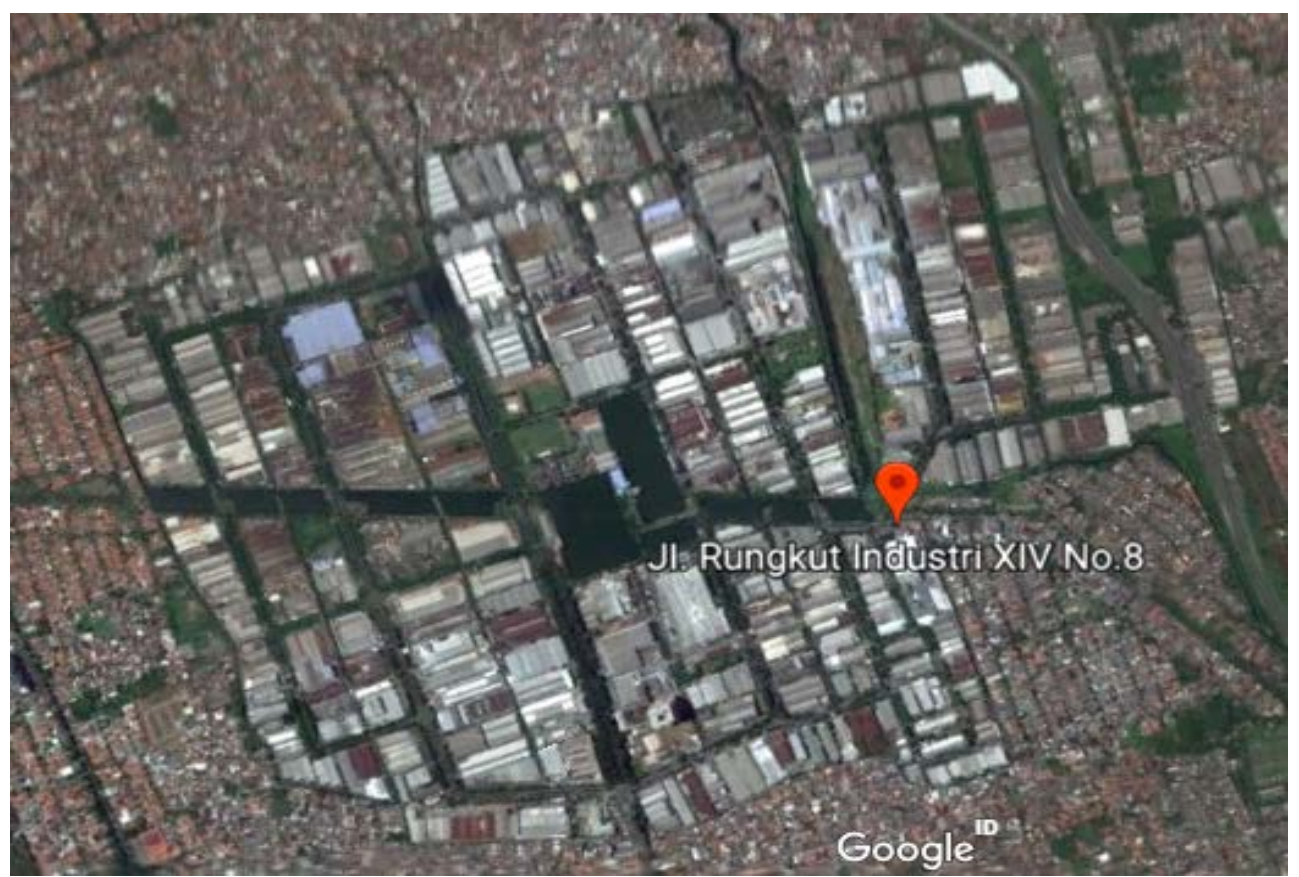

Figure 2.Map of SIER Industrial Area Surabaya

In the picture illustrates the location of research that on the area of industrial industry SIER Surabaya with a total area of 245 ha and is occupied by nearly 300 companies that hold tens of thousands of workers.

Table1.Postal Address Fire Brigade In Surabaya

\begin{tabular}{llc}
\hline \multicolumn{1}{c}{ Post office } & \multicolumn{1}{c}{ Addres } & Telp number \\
\hline Shift I & - & $(031)-3533844$ \\
Shift II & - & $(031)-3534738$ \\
UPTD II & Kenjeran 120 & $(031)-3712208$ \\
UPTD III & Jl. BrebekIndustri III & $(031)-8411113$ \\
UPTD IV & Jl. Raya MengantiWiyung & $(031)-7523687$ \\
UPTD V & Jl. Margomulyo Blok 1/I & $(031)-7590486$ \\
Pegirian Post & Jl. Pegirian No. 240 & $(031)-3736945$ \\
Menur Post & Jl. Menur No. 31 & $(031)-5915987$ \\
Bulak Post & Jl. KyaiTambakderes No.252 & $(031)-51503072$ \\
PostPakal & Jl. Raya Pakal No. 24 & $(031)-7408134$ \\
Central Surabaya & Jl. PasarTuri 21 & $(031)-3533843 / 44$ \\
\hline
\end{tabular}


TiBuana

Journal of applied Industrial Engineering-University of PGRI Adi Buana

\begin{tabular}{lll}
\hline NorthSurabaya & Jl. Kenjeran 1 & $(031)-3712208$ \\
East Surabaya & Jl. RungkutIndustri XIV/8 & $(031)-8411113$ \\
Surabaya Barat & Jl. MargomulyoKomplekSrimulyo & $(031)-7490486$ \\
Surabaya Selatan & Jl. Menganti - Wiyung & $(031)-7523687$ \\
\hline
\end{tabular}

Source : (www. surabaya.go.id)

From the data of postal address of firefighters which enable to reach the industrial area of SIER is fire station Rungkut Industri XIV/8 and fire station Brebek. Distance from Damkar Rungkut Industri XIV/8 to SIER 4.7 KM. The distance from the Brebek fire extinguisher post to SIER 2.2 KM.Analysis of the direction of the distribution of firefighting locations is done descriptively qualitative. Descriptive analysis is done after knowing the suitability between the factors studied with the benchmarks specified.Qualitative descriptive analysis is done by comparing the areas that have not reached the postal service of firefighters and have a high risk potential for fire disaster in SIER Industrial Area Surabaya with criteria determining the location of the firefighting post that has beendone.This analysis is aimed to obtain direction of distribution of firefighting post location based on potential disaster risk of fire at SIER Industrial Area of Surabaya

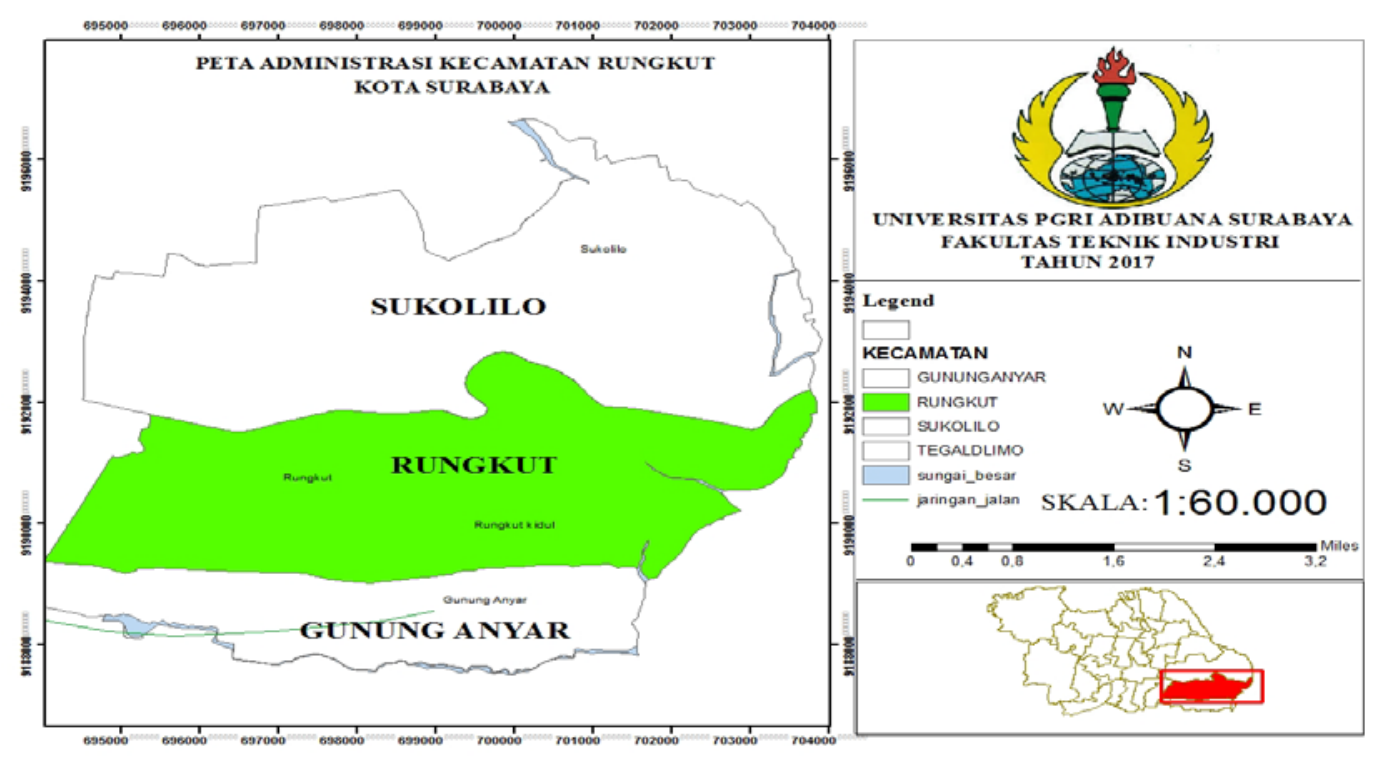

Figure 3.Map of District of Rungkut

In the picture the map depicts Sukolilo, Rungkut and Gunung Anyar districts. In this research focuses on SIER Industrial area Surabaya located in District Rungkut. Regions
SIER industry is also one of the largest industrial areas in East Java, therefore the Industrial area has a higher fire disaster potential than other industrial areas. 


\section{TiBuana}

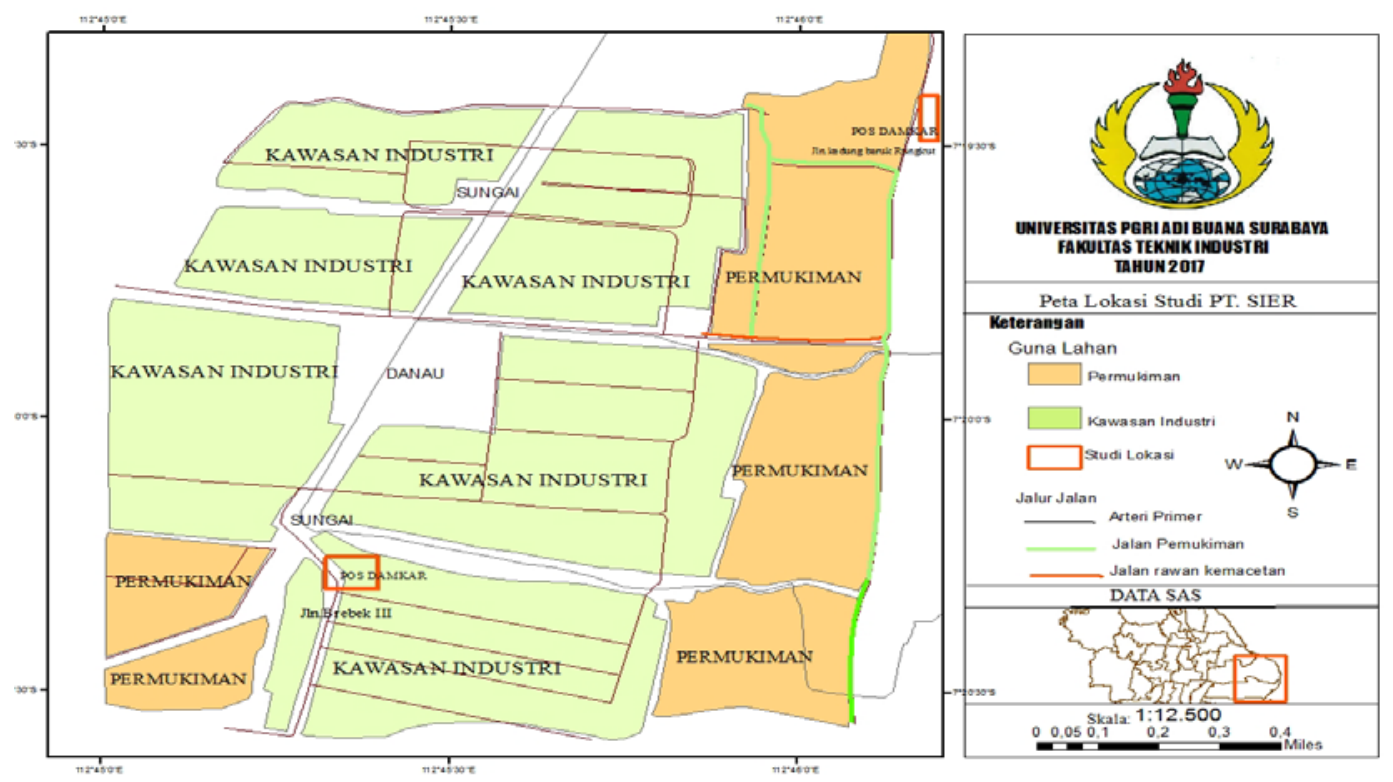

Figure 4.GIS Map of SIER Industrial Estate and Brebek

By using arcGIS can be in the know lane, distance and hazard prone areas in the area of SIER Industry and industrial area of Brebek. Location of firefighting post itself there are two of the fire extinguisher Brebek and firefighters Rungkut Industri with a distance to the SIER Industrial area respectively is $2,2 \mathrm{~km}$ and $4,2 \mathrm{~km}$. From

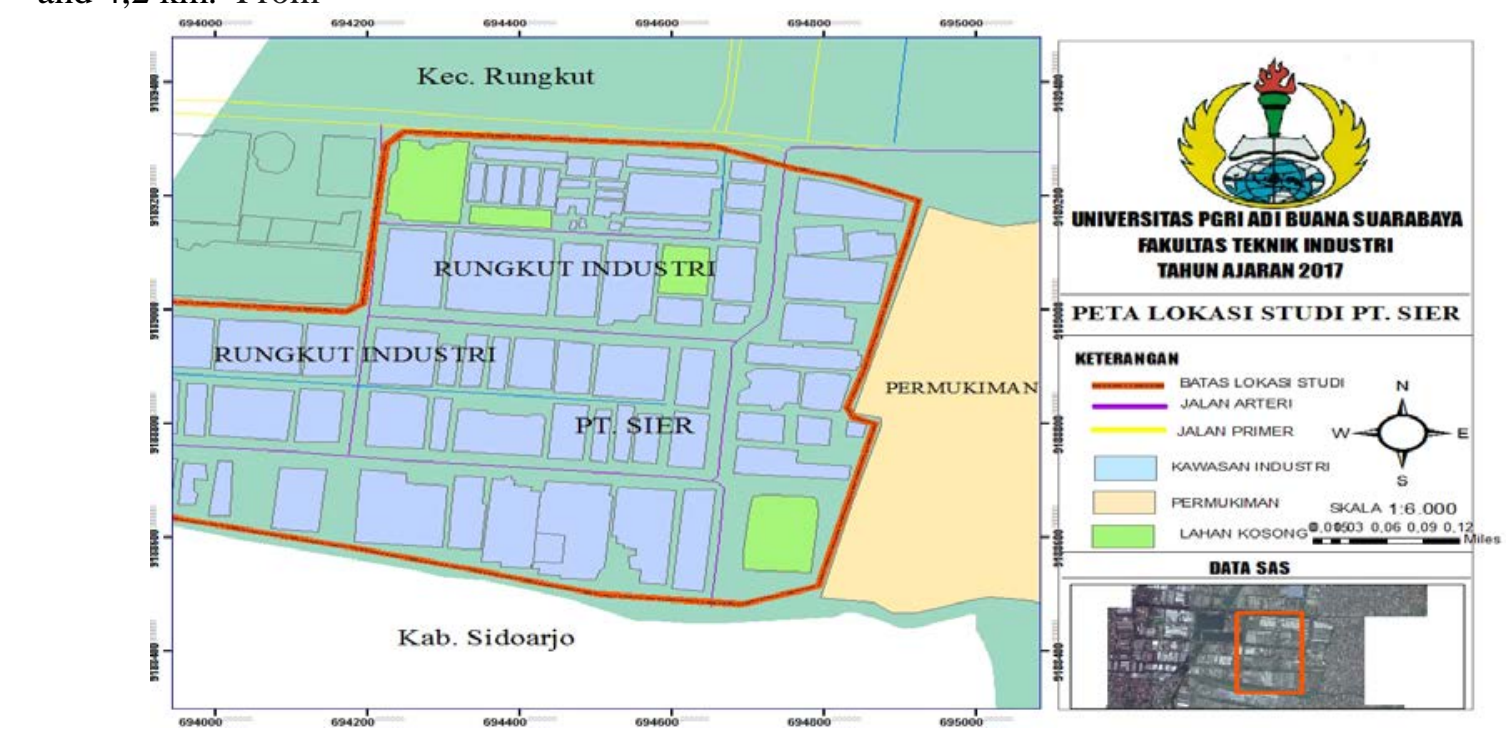

Figure 5.GIS Map of SIER Industrial Area Surabaya

The picture above illustrates the location of SIER Surabaya industrial area which has an area of 245 ha and is occupied by nearly 300 companies that hold tens of thousands of workers. The industrial area of SEER itself this data in the data can be densely populated residential areas located in the vicinity of industrial areas that have the potential of fireprone karna distance in the area of industrial areas. Also described there are jammed roads, arterial roads and also residential roads.

does not have a firefighting post but each company has been equipped or facilitated by providing water or hydrant. Itself if at any time there is a fire incident in the area or company can be overcome and overcome first 
TiBuana

Journal of applied Industrial Engineering-University of PGRI Adi Buana

before the fire truck dating from fire stations around the area of industrial area SIER Surabaya.

Table 2.Comparison table of each damkar post

\begin{tabular}{ccccc}
\hline & Unitdamkarcar & $\begin{array}{c}\text { Distance of } \\
\text { post with } \\
\text { location }\end{array}$ & $\begin{array}{c}\text { Capacity of each } \\
\text { damkarcar with } \\
\text { water }\end{array}$ & $\begin{array}{c}\text { Number of } \\
\text { personnel of } \\
\text { damkar post }\end{array}$ \\
\hline DamkarPostbrebek & 2 & $2,2 \mathrm{~km}$ & $8.000 \mathrm{~L}$ & 30 \\
$\begin{array}{c}\text { PostRungkutIndustri } \\
\text { XIV/8 }\end{array}$ & 1 & $4,2 \mathrm{~km}$ & $5.000 \mathrm{~L}$ & 15
\end{tabular}

Source : Data processing, 2017

Data processing used in this research is using NWCwith the following calculation:

Table 3.Calculation NWC step 1

\begin{tabular}{|c|c|c|c|c|c|c|c|}
\hline & \multicolumn{2}{|c|}{ A } & \multicolumn{2}{|c|}{ B } & \multicolumn{2}{|c|}{ C } & Total \\
\hline Rungkut & & 15 & & 12 & & 16 & 50 \\
\hline Brebek & & 17 & & 19 & & 18 & 75 \\
\hline Total & 40 & & 45 & & 40 & & 125 \\
\hline
\end{tabular}

Source : Data processing, 2017

First step, fullfill the request A [40] with post damkar Rungkut [15] (so post damkar Rungkut still left 25)

Table 4. Calculation NWC step 2

\begin{tabular}{|c|c|c|c|c|c|c|c|}
\hline & \multicolumn{2}{|c|}{$\mathrm{A}$} & \multicolumn{2}{|c|}{ B } & \multicolumn{2}{|c|}{$\mathrm{C}$} & Total \\
\hline Rungkut & 40 & 15 & & 12 & & 16 & 50 \\
\hline Brebek & & 17 & & 19 & & 18 & 75 \\
\hline Total & 40 & & 45 & & 40 & & 125 \\
\hline
\end{tabular}

Source : Data processing, 2017

Alternative request of road through line A has been fulfilled, hence from that alternative road through path A we make that alternative way through path A not will be included in the next calculation. Continue to meet the demand of Rungkut city [12], take the remaining capacity of Rungkut [25] 
Table 5.Calculation NWC step 3

\begin{tabular}{|c|c|c|c|c|c|c|c|}
\hline & \multicolumn{2}{|c|}{$\mathrm{A}$} & \multicolumn{2}{|c|}{ B } & \multicolumn{2}{|c|}{ C } & Total \\
\hline Rungkut & 40 & 15 & 10 & 12 & & 16 & 50 \\
\hline Brebek & & 17 & & 19 & & 18 & 75 \\
\hline Total & 40 & & 45 & & 40 & & 125 \\
\hline
\end{tabular}

Source : Data processing , 2017

Request Rungkut has been fulfilled, then Rungkut we shading as a markerthat Rungkut will not be included in the next calculation

Table 6.Calculation NWC step 4

\begin{tabular}{|c|c|c|c|c|c|c|c|}
\hline & \multicolumn{2}{|c|}{ A } & \multicolumn{2}{|c|}{ B } & \multicolumn{2}{|c|}{$\mathrm{C}$} & \multirow{2}{*}{$\begin{array}{l}\text { Totall } \\
50\end{array}$} \\
\hline Rungkut & 40 & 15 & 10 & 12 & & 16 & \\
\hline Brebek & & 17 & 35 & 19 & & 18 & 75 \\
\hline Total & 40 & & 45 & & 40 & & 125 \\
\hline
\end{tabular}

Source : Data processing , 2017

Furthermore, to fulfill the alternatives of path $\mathrm{B}$ we fill by filling [35] at Brebek, so it is on Brebek a marker that Berbek passes through path $B$ will not be included in the next calculation.

Table 7.Calculation NWC step 5

\begin{tabular}{|c|c|c|c|c|c|c|c|}
\hline & \multicolumn{2}{|c|}{$\mathrm{A}$} & \multicolumn{2}{|c|}{ B } & \multicolumn{2}{|c|}{$\mathrm{C}$} & Total \\
\hline Rungkut & 40 & 15 & 10 & 12 & & 16 & 50 \\
\hline Brebek & & 17 & 35 & 19 & 40 & 18 & 75 \\
\hline Total & 40 & & 45 & & 40 & & 125 \\
\hline
\end{tabular}

Source : Data processing , 2017

Furthermore, to fulfill the alternative of the C path we fill it by filling [40] at Brebek, so in
Brebek passing through the $\mathrm{C}$ line we shade as a marker that Brebek passing through line $\mathrm{C}$ will not 
TiBuana

Journal of applied Industrial Engineering-University of PGRI Adi Buana

be included in the next calculation. For the next step, we will calculate the nearest distance can be passed as follows

$$
=15(40)+12(10)+19(35)+18(40)
$$

\section{Conclusion}

From the results of the analysis of the discussion that has been described, it can be concluded that to determine the closest distance for the distribution of fire trucks in the industrial area of SIER Surabaya can use the application in GIS by using NWC calculation which will be applied to form the recommendation point of the fire station and its rangeusing NWC calculations which will be applied to form the fire fighting recommendation point and its range is more optimal, and in determining the location of public facilities must meet several criteria, among others:

- The criteria for minimizing the average distance traveled by residents from

\section{Reference}

1. Bogir, Mohammad. 2009. Model Optimasi Lokasi Pos Pemadam Kebakaran (SK : Kota Semarang). Skripsi Jurusan Perencanaan Wilayah dan Kota. Semarang. Universitas Diponegoro.

2. http://surabaya.go.id/home/dishub

3. KetentuanTeknisPengamananTerhadapBa hayaKebakaranPadaBangunanGedu

$$
\begin{aligned}
& =600+120+665+720 \\
& =2105 \mathrm{~m}
\end{aligned}
$$

So the closest distance to get to industrial area of SIER Surabaya is 2105 meter.

residence to the nearest service center should be minimum.

- If the population around the service center is the same, then the burden borne by the service center should also be the same.

- The service center should be able to meet the capacity threshold value if the population around the service center exceeds the specified limits

Factors that influence the determination of the location of firefighting post are accessibility (mileage, travel time and road capacity), fire risk level (land use intensity and land use), population, service effectiveness (level and service scale, distribution pattern of existing facility ) and policies.

ngdanLingkungan,

YayasanBadanPenerbit PU. Jakarta.

4. Sunyoto, Danang, "Dasar - dasar

matematika ekonomi terapan

“,Total Media, Yogyakarta, 2009

5. Widiyanto, Wirawan. "Pemintakatan

Kawasan Risiko Bencana

Kebakaran di Kota Surabaya”. (2010). Institut Teknologi Sepuluh Nopember. Surabaya. 